\title{
EVALUATION OF GAS CHROMATOGRAPHY-MASS SPECTROMETRY AND CYTOTOXICITY OF ETHANOLIC LEAF EXTRACT OF ACACIA CAESIA (L.) WILLD. AGAINST HELA CELL LINE
}

\author{
SHARMILA S*, RAMYA E K \\ PG and Research Department of Botany, Vellalar College for Women, Thindal, Erode - 638 012, Tamil Nadu, India. Email: drsharmilas@yahoo.com \\ Received: 06 April 2018, Revised and Accepted: 10 September 2018
}

\section{ABSTRACT}

Objective: The objective of this study is to analyze the bioactive compounds of the ethanolic leaf extract of Acacia caesia using gas chromatographymass spectrometry (GC-MS) method and also screen the in vitro cytotoxic activity against HeLa-E 72 cancer cell line.

Methods: The present research was carried out using GC-MS analysis, while mass spectra of the compounds found in the extract were matched with the National Institute of Standards and Technology and Wiley library. Cytotoxicity was assessed with 3-[4,5-dimethylthiazol-2-yl]2,5-diphenyltetrazolium bromide assay, and cellular morphological alterations were studied using phase contrast inverted light microscope of 400x. The ethanol extract of A. caesia was screened for their cytotoxicity at different concentrations (12.5-200 $\mu \mathrm{g} / \mathrm{ml})$, to determine the mean percentage (\%) cell viability.

Results: The results of GC/MS analysis showed the presence of 41 major compounds. In terms of percentage amounts, 1,8-diphenyl-3,4,10,11tetrahydro[1,4] dioxino[2,3-g:5,6-g'] diisoquinoline, 6-(chloromethyl)-4-(3,4-dimethoxy-2-(phenylmethoxy)-phenyl)-3-methyl-2-yridinecarboxylate, and 2',4',6'-Trinitro-5'-phenyl-1,1':3',1'-terphenyl were predominant in the extract and have the property of antioxidant, antidepressant potential, antibacterial activity, cytotoxic, diabetic, and induced brain activity. The results of cytotoxicity at highest concentration (200 $\mu \mathrm{g} / \mathrm{ml})$ of the cells became rounder, shrunken and showed signs of detachment from the surface of the wells denoting cell death.

Conclusions: From this study, it is obvious that $A$. caesia leaf extracts contain various bioactive constituents with a wide range of medicinal properties which is used to treat multiple disorders and it also gives a detailed insight about the phytochemical profile which could be exploited for the development of plant-based drugs. Further, the ethanolic extract of $A$. caesia exhibits potent cytotoxic activity against HeLa-E 72 cell line.

Keywords: Acacia caesia, Gas chromatography-mass spectrometry analysis, Cytotoxic, Bioactive compounds.

(C) 2019 The Authors. Published by Innovare Academic Sciences Pvt Ltd. This is an open access article under the CC BY license (http://creativecommons. org/licenses/by/4. 0/) DOI: http://dx.doi.org/10.22159/ajpcr.2019.v12i1.26470

\section{INTRODUCTION}

India is the principal producer of medicinal aromatic herbs and is aptly called the botanical arboretum of the world [1]. Plants are capable of synthesizing an overwhelming variety of low-molecular weight organic compounds called secondary metabolites, usually with unique and complex structures. The most vital bioactive constituents of the plants are alkaloids, tannins, flavonoids, and phenolic compounds. A lot of metabolites have been found to possess interesting biological activities and find applications, such as pharmaceuticals, insecticides, dyes, flavors, and fragrances. Plants used for traditional medicine contain a wide range of substances that can be used to treat chronic as well as infectious diseases [2]. Medicinal plants are at curiosity to the field of biotechnology as well as most of the drug industries depend on plant parts for the future production of pharmaceutical compounds [3].

Acacia caesia is a locally used medicinal plant species belonging to Mimosaceae family. It is an armed woody straggling shrub generally inhabiting the foothills of Western Ghats of Coimbatore District and Erode District, Tamil Nadu, India. The local name of the species is "Kari indu or Indamul." It is commonly known as "Babool" in India. It is highly valuable plant which is used for the treatment of skin, sexual problems, wound, stomach, and tooth problems. Still, many herbal products derived from Acacia species are sold in markets in pure or mixed forms such as babool toothpaste, Ayur shampoo, and Nyle shampoo. All Acacias are suitable materials for fuel, forage, soil fertility, and soil conservation $[4,5]$. In Indian systems of medicine, A. caesia is a strong antioxidant medicinal plant.

Extraction is the main step for the recovery and isolation of bioactive phytochemicals from plant materials, before component analysis [6]. In the past few years, gas chromatography-mass spectrometry (GC-MS) has become firmly established as a key technological platform for secondary metabolite profiling in both plant and non-plant species $[7,8]$. GC-MS is a method that combines the features of gas-liquid chromatography and MS to identify different substances within a test sample. However, few reports are available with respect to the pharmacological properties of the study plant. Keeping this in view, the present study has been undertaken to investigate the in vitro cytotoxic activity and identify the phytoconstituents present in the ethanolic leaf extract of $A$. caesia using GC-MS analysis.

\section{METHODS}

Collection and identification of plant material

The fresh leaves of A. caesia were collected from the Maruthamalai Hill (arid; $540 \mathrm{~m}$ above msl; dry deciduous forest), Coimbatore District (a part of the Western Ghats of Western Tamil Nadu) (Plate 1). The collected study plant was identified with the help of the existing floras [9-11] and compared with type specimens available in the herbarium of the Botanical Survey of India, Southern Circle, Tamil Nadu Agricultural University Campus, Coimbatore, Tamil Nadu (Voucher specimen No. BSI/SRC/5/23/2015/TECH/343).

\section{Preparation of extract}

The leaf was shade dried, and it was made as a powder using electrical blender. About $500 \mathrm{~g}$ of coarse powder of shade-dried leaves of $A$. caesia was extracted successively with ethanol $\left(78.5^{\circ} \mathrm{C}\right)$ in Soxhlet extractor for $6 \mathrm{~h}$. The solvent extract was concentrated and vacuum dried. The obtained extract was stored in a desiccator for further GC-MS and in vitro cell line studies. 


\section{GC-MS analysis}

\section{GC-MS conditions}

The ethanolic extract was subjected to GC-MS analysis on the instrument-THERMO MS DSQ II-TR, 5-MS capillary standard nonpolar column, and the GC-MS trace ultra version 5.0 software employing the following conditions: ZB x 5 MS Capillary standard Non-polar column $(30 \mathrm{~mm} \times 0.25 \mathrm{~mm} \mathrm{ID} \times 1 \mu \mathrm{M}$ df, composed of $100 \%$ dimethylpolydiloxane). Initially, oven temperature was maintained at $70^{\circ} \mathrm{C}$ for $2 \mathrm{~min}$, and the temperature was gradually increased up to $260^{\circ} \mathrm{C}$ at $6^{\circ} \mathrm{C} / \mathrm{Min}$ and $1 \mu \mathrm{L}$ of sample was injected for analysis. Helium gas $99.995 \%$ of purity was used as a carrier gas as well as a eluent. The flow rate of helium gas was set to $1 \mathrm{~mL} / \mathrm{min}$. The sample injector temperature was maintained at $260^{\circ} \mathrm{C}$, and the split ratio is 6 throughout the experiment periods. The ionization mass spectroscopic analysis was done with $70 \mathrm{eV}$. The mass spectrum was recorded for the mass range $40-1000 \mathrm{~m} / \mathrm{z}$ for about $38.53 \mathrm{~min}$.

\section{Identification of compounds}

The identification of compounds was based on the comparisons of their mass spectra with NIST Library 2008, WILEY8 and FAME [12]. Mass spectrum of individual unknown compound was compared with the known compounds stored in the software database libraries. The name, molecular weight, and components structure of test material were ascertained.

\section{In vitro cytotoxicity studies}

Cell line

The human cervical cancer cell line (HeLa-E 72) was obtained from the National Center for Cell Science (NCCS), Pune, and grown in Eagles Minimum Essential Medium containing 10\% fetal bovine serum (FBS). The cells were maintained at $37^{\circ} \mathrm{C}, 5 \% \mathrm{CO}_{2}, 95 \%$ air, and $100 \%$ relative humidity. Maintenance of culture was passage weekly, and the culture medium was changed twice a week.

\section{Cell treatment procedure}

The monolayer cells were detached with trypsinethylenediaminetetraacetic acid to make single cell suspension. Viable cells were counted by trypan blue exclusion using a hemocytometer and diluted with medium containing 5\% FBS to give a final density of $1 \times 10^{5}$ cells $/ \mathrm{ml}$. One hundred microlitres per well of cell suspension were seeded into 96-well plates at plating density of 10,000 cells/well and incubated to allow for cell attachment at $37^{\circ} \mathrm{C}, 5 \% \mathrm{CO}_{2}, 95 \%$ air, and $100 \%$ relative humidity. After $24 \mathrm{~h}$, the cells were treated with serial concentrations of the test samples. They were initially dissolved in neat dimethylsulfoxide (DMSO), and an aliquot of the sample solution was diluted to twice the desired final maximum test concentration with serum-free medium. Additional four serial dilutions were made to provide a total of five sample concentrations. Aliquots of $100 \mu \mathrm{l}$ of these different sample dilutions were added to the appropriate wells already containing $100 \mu \mathrm{l}$ of medium, resulting in the required final sample concentrations. Following sample addition, the plates were incubated for an additional $48 \mathrm{~h}$ at $37^{\circ} \mathrm{C}, 5 \% \mathrm{CO}_{2}, 95 \%$ air, and $100 \%$ relative humidity. The medium containing without samples were served as control, and the triplicate was maintained for all concentrations.

\section{3-[4,5-dimethylthiazol-2-yl]2,5-diphenyltetrazolium bromide (MTT) assay}

MTT is a yellow water-soluble tetrazolium salt. A mitochondrial enzyme in living cells, succinate-dehydrogenase, cleaves the tetrazolium ring, converting the MTT to an insoluble purple formazan. Therefore, the amount of formazan produced is directly proportional to the number of viable cells.

After $48 \mathrm{~h}$ of incubation, $15 \mu \mathrm{l}$ of MTT $(5 \mathrm{mg} / \mathrm{ml})$ in phosphate-buffered saline (PBS) was added to each well and incubated at $37^{\circ} \mathrm{C}$ for $4 \mathrm{~h}$. The medium with MTT was then flicked off, and the formed formazan crystals were solubilized in $100 \mu \mathrm{l}$ of DMSO and then measured the absorbance at $570 \mathrm{~nm}$ using microplate reader. The percentage of cell viability was then calculated with respect to control as follows:

cell viability $=\frac{\text { Absorbance of treated cell }}{\text { Absorbance of control cell }\left(\begin{array}{l}\text { Cell proliferation in } \\ \text { comparison to control } \\ \text { will be counted as } \\ \text { positive samples }\end{array}\right)} \times 100$

\section{Observation of cell by phase contrast microscope}

Media were removed from the ethanolic extract and treated cells were washed with PBS. They were observed by phase-contrast inverted microscope of $400 \times$. The morphological changes were observed in HeLa-E 72 cell line.

\section{RESULTS AND DISCUSSION}

\section{GC-MS analysis}

The components present in the ethanolic leaf extract of $A$. caesia were identified by GC-MS analysis. The GC-MS chromatogram of the number of peaks of the compounds detected is shown in Fig. 1. This analysis reveals the presence of phytoconstituents belonging to the type-acids, esters, alcohols, and ether group. Phytocomponents identified from the ethanolic leaf extract of Acacia caesia leaves by GC-MS analysis and Mass spectrum and compound structure of phytocomponents identified by GC-MS in ethanolic leaf extract of Acacia caesia were given in Table 1 and 2. The identified compound bioactivities were predicted using Dr. Duke's Phytochemical and Ethnobotanical Databases [13].

The spectrum profile of GC-MS confirmed the presence of 10 major peaks with retention time $36.71,34.61,29.46,26.94,23.82,17.96$, $13.14,10.35,8.66$, and 5.83, respectively (Fig. 1).

Tables 1 and 2 list the major phytocomponents, their molecular formula, molecular weight, probability percentage, chemical structure, and biological activities obtained through the GC-MS study

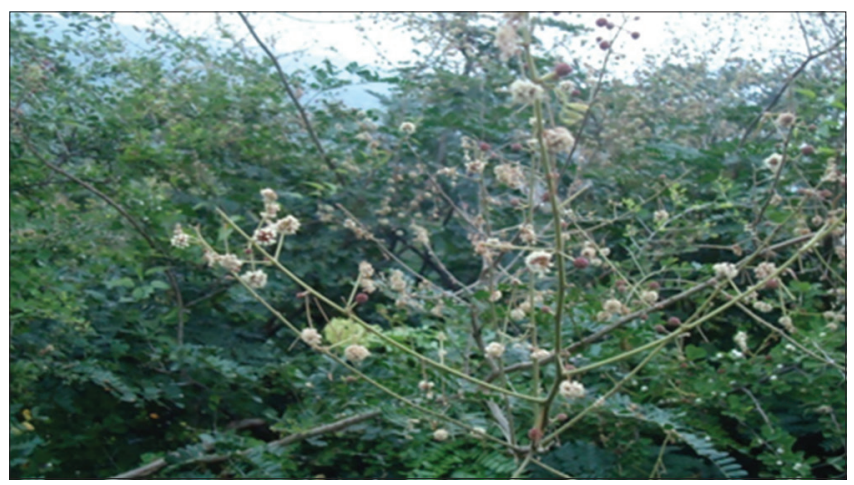

Plate 1: Habit of Acacia caesia in blooming stage

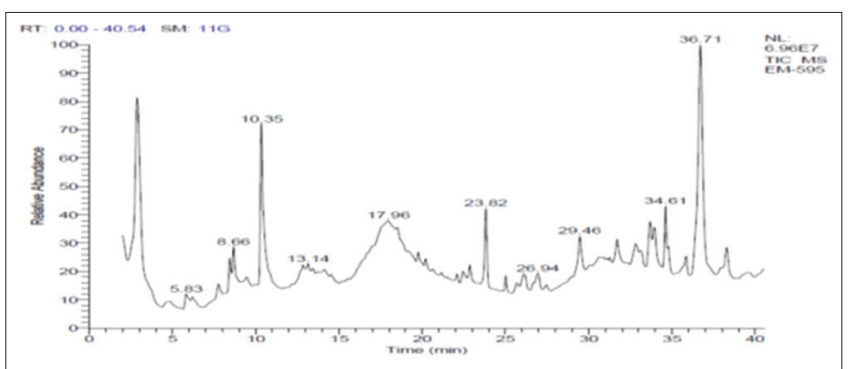

Fig. 1: Gas chromatography-mass spectrometry profile of the ethanolic leaf extract of Acacia caesia 
Table 1: Phytocomponents identified from the ethanolic leaf extract of Acacia caesia leaves by GC-MS analysis

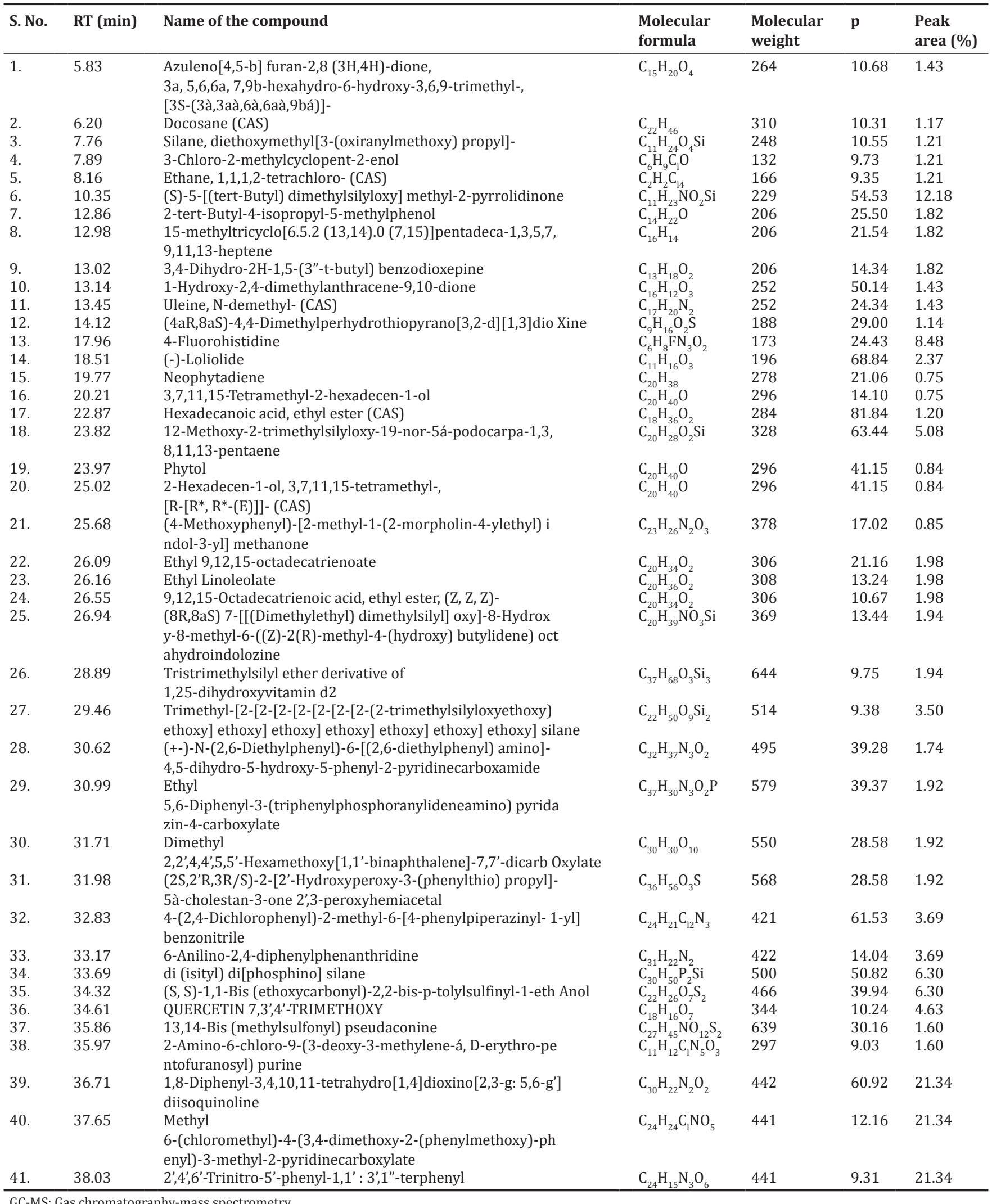

of $A$. caesia. In the present study, the GC-MS analysis of the ethanolic leaf extract of $A$. caesia showed the presence of 41 major compounds (Table 1). In terms of percentage amounts, 1,8-diphenyl-3,4,10,11tetrahydro[1,4]dioxino[2,3-g:5,6-g']diisoquinoline, 6-(chloromethyl)-
4 - (3,4-dimethoxy-2-(phenylmethoxy)-phenyl)-3-methyl-2yridinecarboxylate, and 2',4',6'-Trinitro-5'-phenyl-1,1':3',1'-terphenyl were predominant in the extract and have the property of antioxidant, antidepressant potential, antibacterial activity, cytotoxic, diabetic, 


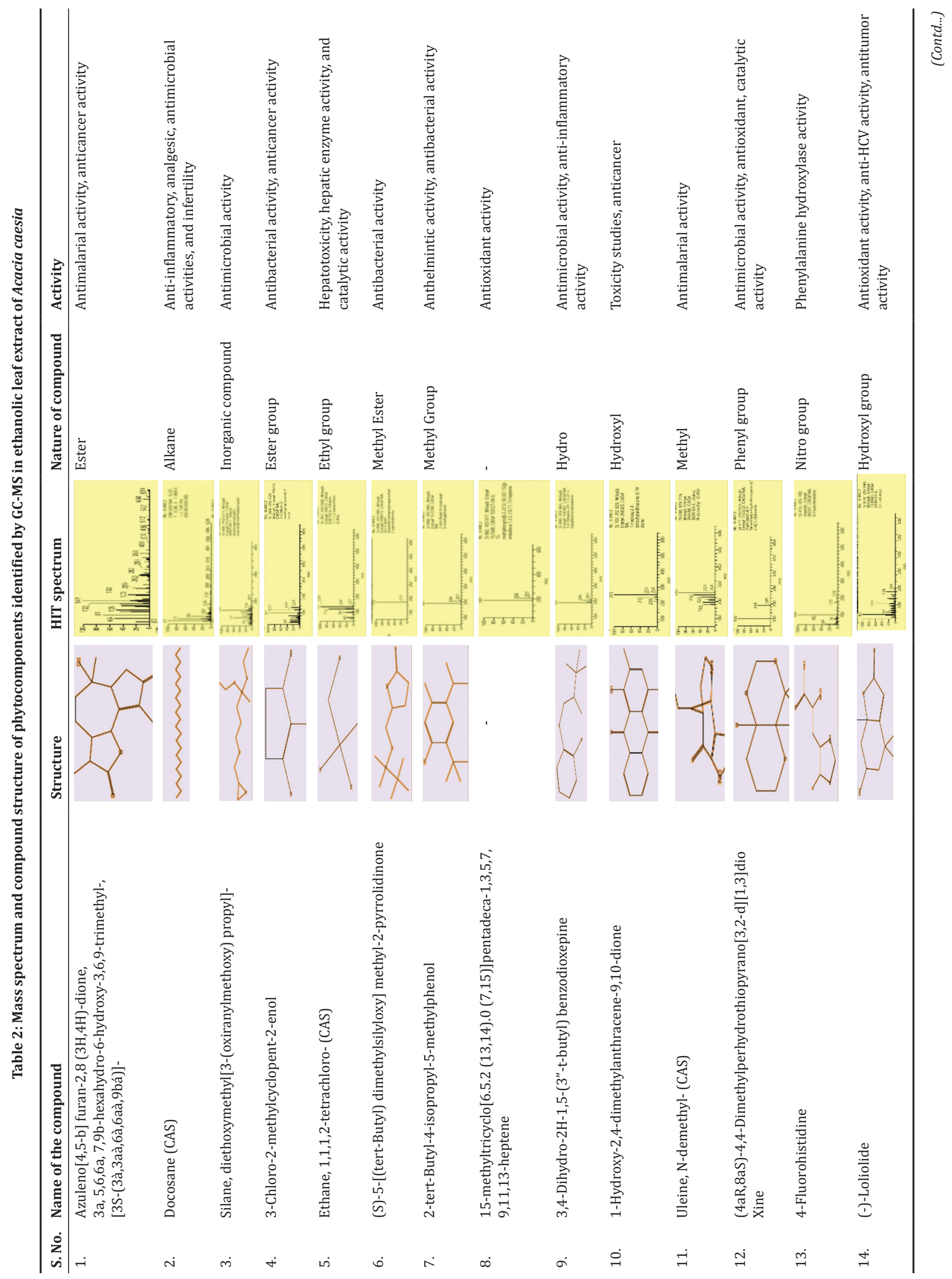




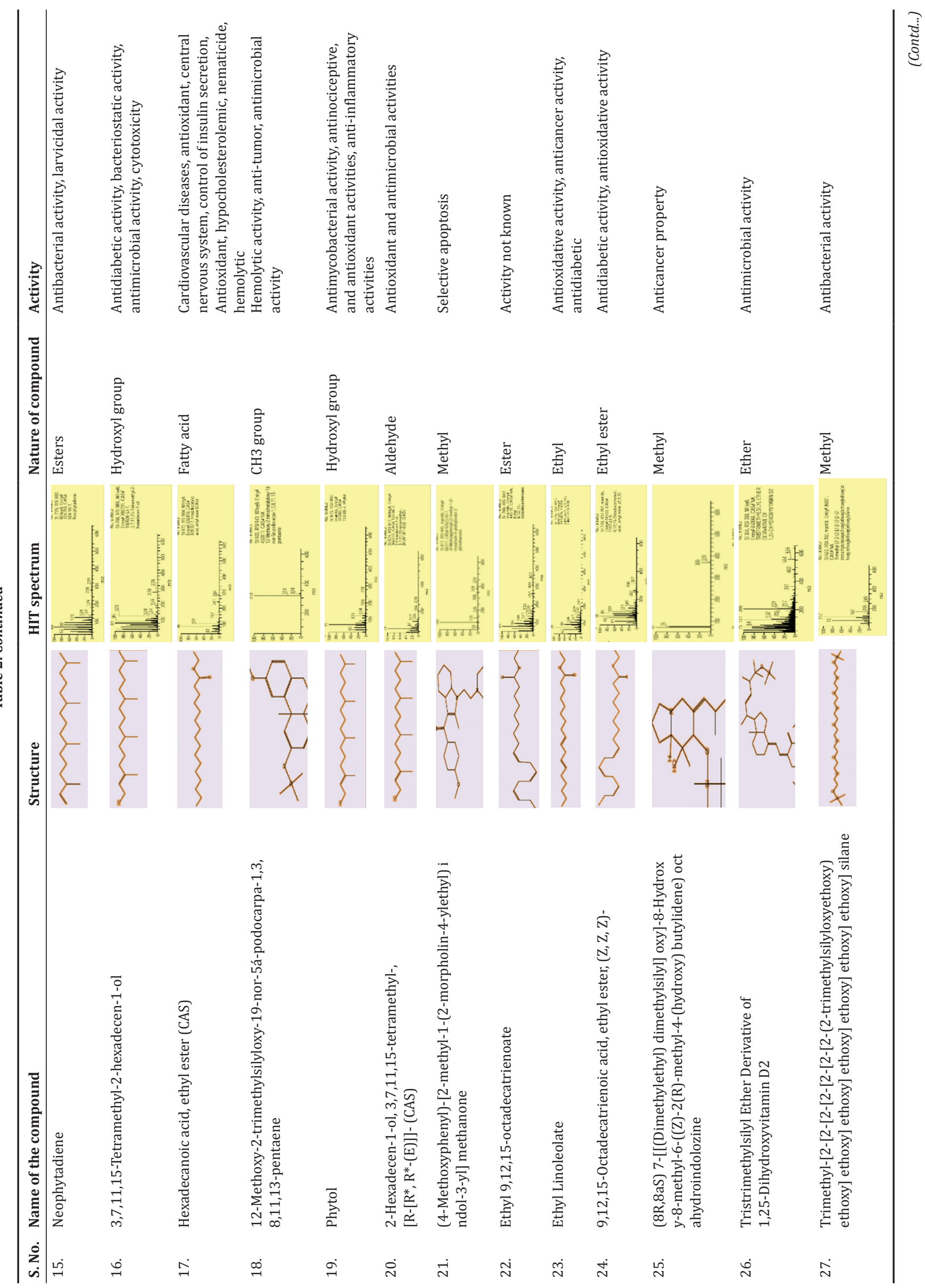




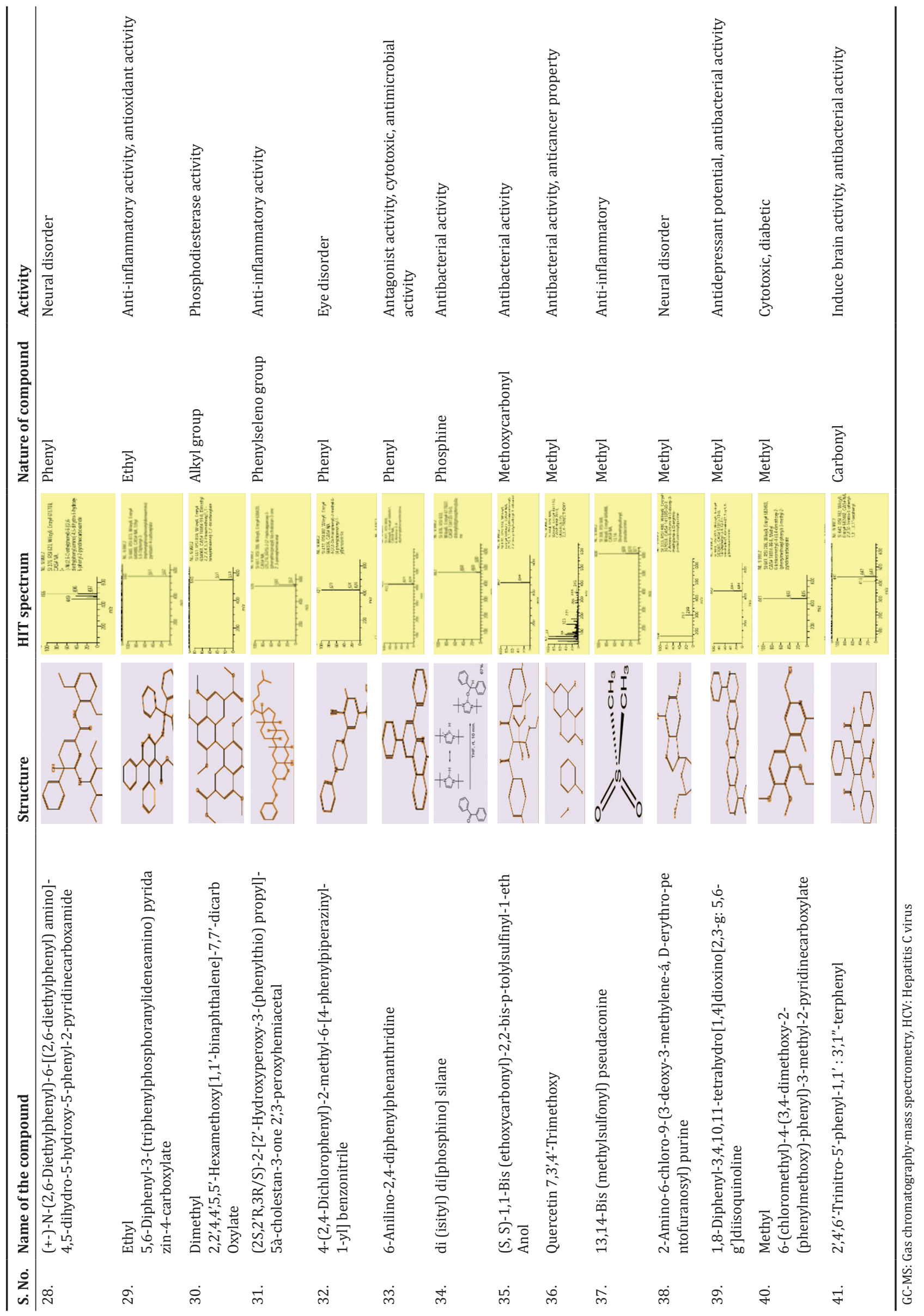


Table 3: MTT assay for in vitro cytotoxic activity of the ethanolic leaf extract of Acacia caesia

\begin{tabular}{|c|c|c|c|c|c|c|}
\hline \multirow[t]{2}{*}{ S. No. } & \multirow[t]{2}{*}{ Concentration $(\mu \mathrm{g} / \mathrm{ml})$} & \multicolumn{5}{|c|}{ Cervical cancer cell line (HeLa) } \\
\hline & & \multicolumn{3}{|c|}{ Ethanolic extract } & \multirow{2}{*}{$\begin{array}{l}\text { Average } \\
0.512\end{array}$} & \multirow{2}{*}{ Cell viability $(\%)$} \\
\hline 1. & Control & 0.507 & 0.507 & 0.523 & & \\
\hline 3. & 25 & 0.51 & 0.524 & 0.524 & 0.519 & 101.3663 \\
\hline 4. & 50 & 0.504 & 0.51 & 0.493 & 0.502 & 98.04815 \\
\hline 5. & 100 & 0.482 & 0.495 & 0.494 & 0.490 & 95.70592 \\
\hline 6. & 200 & 0.388 & 0.382 & 0.395 & 0.388 & 75.79701 \\
\hline
\end{tabular}

MTT: 3-[4,5-dimethylthiazol-2-yl] 2,5-diphenyltetrazolium bromide

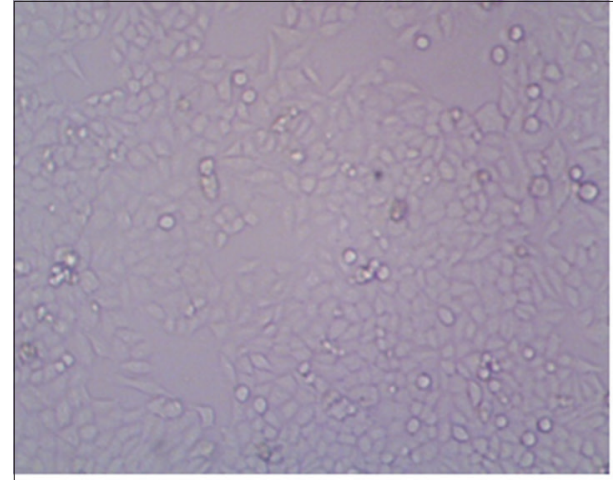

Control

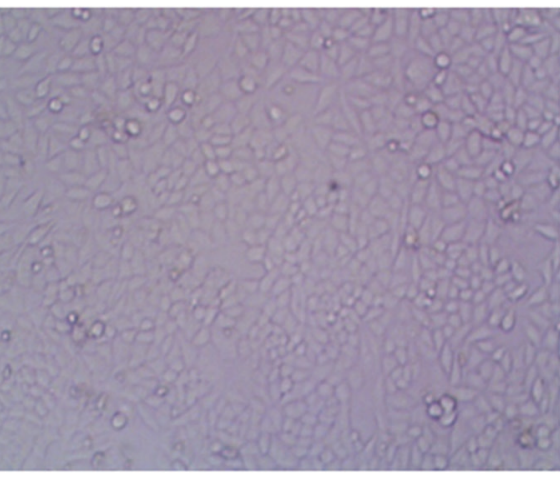

$25 \mu \mathrm{g} / \mathrm{ml}$

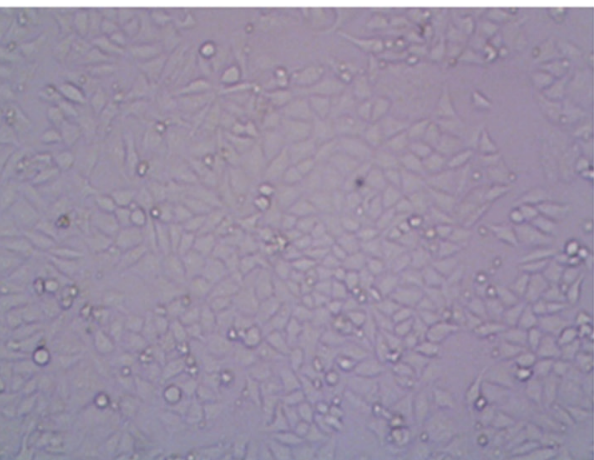

$100 \mu \mathrm{g} / \mathrm{ml}$

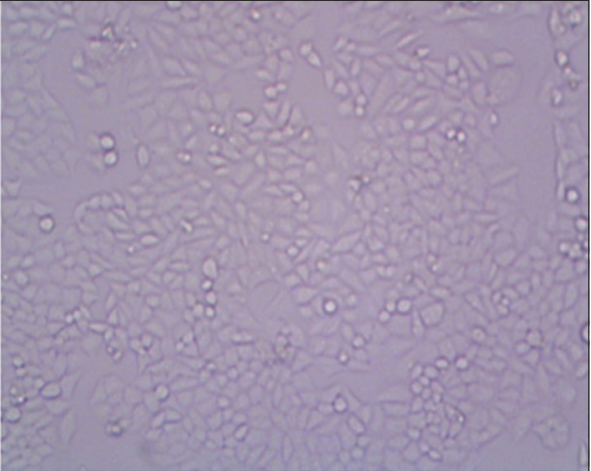

$12.5 \mu \mathrm{g} / \mathrm{ml}$

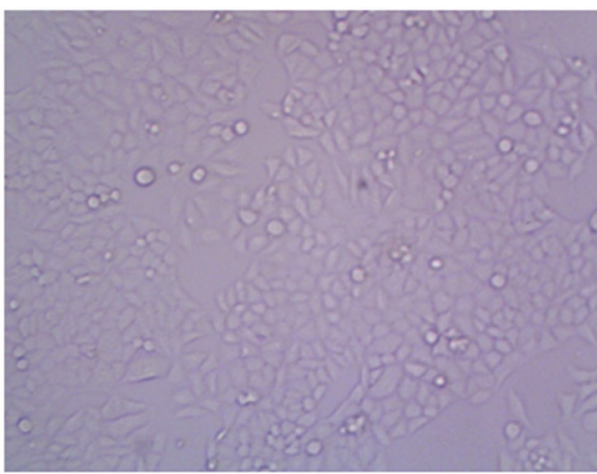

$50 \mu \mathrm{g} / \mathrm{ml}$

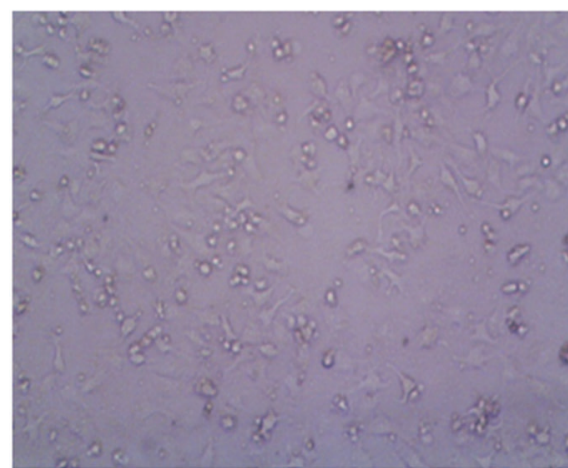

$200 \mu \mathrm{g} / \mathrm{ml}$

Plate 2: Morphological changes after the exposure of various concentrations $(12.5-200 \mu \mathrm{g} / \mathrm{ml})$ of ethanolic extract of Acacia caesia on HeLa cell line for $24 \mathrm{~h}$ time duration 


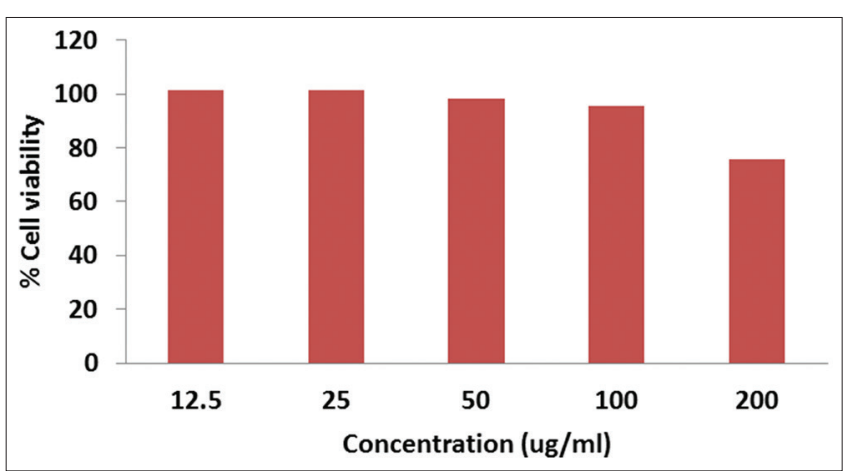

Fig. 2: 3-[4,5-dimethylthiazol-2-yl]2,5-diphenyltetrazolium bromide assay for in vitro cytotoxic activity of the ethanolic leaf extract of Acacia caesia

and induced brain activity (Table 2). Among the other identified phytochemicals, the fatty acid esters, namely, hexadecanoic acid, azulene, enol, ethane, neophytadiene, and octadecatrienoic ester have the property of antioxidant, cardiovascular diseases, central nervous system, control of insulin secretion, nematicide, hypotensive, nimaticide, and pesticide activities [14]. Silane is the inorganic compound which has the property of antimicrobial activity. Docosane, alkane group, has the property of anti-inflammatory, analgesic, and antimicrobial activities and infertility. The squalene has antioxidant and chemopreventive activity against the colon carcinogenesis. Hexadecanoic acid (palmitic acid) is a fatty acid, and it may be an active antimicrobial, cytotoxic, and antidiarrheal agent [15-17].

The mass spectra are fingerprint of that compound which can be identified from the data library. This report is the first of its kind to analyze the chemical constituents of A. caesia using GC-MS. In addition to this, the results of the GC-MS profile can be used as pharmacognostical tool for the identification of study plant. The presence of various bioactive compounds confirms the application of A. caesia for the various ailments by traditional practitioners. However, isolation of individual phytochemical constituents may proceed to find a novel drug.

\section{In vitro cytotoxic effect}

Ethanol extract of $A$. caesia was screened for their cytotoxicity against $\mathrm{HeLa}$ cell lines at different concentrations $(12.5 \mu \mathrm{g} / \mathrm{ml}$ to $200 \mu \mathrm{g} / \mathrm{ml})$, to determine the mean percent (\%) cell viability by MTT assay (Table 3 ). Test concentration was set at as the criteria for identifying plants with potent activity within range. Dose-dependent percentage of cell viability of the plant extract was studied on cell proliferation (101.4964-75.79701). Results are graphically represented in Fig. 2. All cytotoxic activity was assessed at $24 \mathrm{~h}$ time duration. The plant extracts demonstrated antiproliferative activities on the growth of HeLa cell lines.

Morphological alteration of HeLa-E 72 cell line on exposure using A. caesia extract was observed under phase-contrast microscope. The trypan blue exclusion method was utilized to predict the percentage of cell viability on cytostatic effects. The ethanolic extract at $200 \mu \mathrm{g} / \mathrm{ml}$ showed better antiproliferative effect (Plate 2). The cells indicated the most prominent effects after exposure to the plant extract. The microscopic observations revealed the study plant extract to be having outstanding effect on treated HeLa cells compared to untreated cells. The number of dead cells increased correspondingly with the concentration increment of the extract treatment in regards to observation. At high extract concentration, enlargement of the cells was conspicuously observed. The percentage concentration at $40-50 \%$ of the cells showed that membrane blebbing (demonstrated with small protrusions of the membrane) and ballooning were apparent in the cells. The presence of apoptotic bodies could also be seen in the extract-treated cells. Cells also showed extensive vacuolation in the cell cytoplasm, indicating autophagy-like mechanism of cell death. Autophagosome like structures was clearly seen in the cells treated with plant extract. At highest concentration $(200 \mu \mathrm{g} / \mathrm{ml})$, the cells became rounder, shrunken, and showed signs of detachment from the surface of the wells denoting cell death. The assumption was that such activity elicited in the plants crude state would be indicative of even greater potent effects in the purified state. This is in accordance with the results of Samaha et al. [18,19].

\section{CONCLUSION}

The correlation among the active constituents with their biological activities is now being the matter of innovative thought. A. caesia is a plant, traditionally used for the treatment of skin, sexual problems, wound, stomach, and tooth problems. However, till date, there are few reports on chromatographic analysis of study plant. Here, we report the presence of some important compounds in this plant isolated by GC-MS analysis. Thus, this type of study may give information on the nature of active principles present in the medicinal plants. These identified phytoconstituents presumed to be responsible for eliciting the traditional activity of this plant $A$. caesia. The results of our in vitro cancer study revealed that the extract of $A$. caesia exhibits potent cytotoxic activity against HeLa-E 72 cell line. Further, in vivo and in vitro with different human cell lines study are required to demonstrate the antitumor activity of this plant and isolated the lead compound responsible for this activity, which might be utilized for the development of novel anticancer drug.

\section{ACKNOWLEDGMENT}

The Authors of this paper thanks to University Grants Commission, Hyderabad, India, for funding as minor research project.

\section{AUTHORS' CONTRIBUTIONS}

Dr. S. Sharmila designed the study, performed the GC/MS analysis, and wrote the first draft of the manuscript. My scholar E.K. Ramya managed the literature searches. Finally, the corresponding author approved the final manuscript.

\section{CONFLICTS OF INTEREST}

The authors declare that they have no conflicts of interest.

\section{REFERENCES}

1. Ahmedull M, Nayar MP. Red Data Book for Indian plants. Calcutta: Botanical Survey of India; 1999. p. 4.

2. Duraipandiyan V, Ayyanar M, Ignacimuthu S. Antimicrobial activity of some ethnomedicinal plants used by paliyar tribe from Tamil Nadu, India. BMC Complement Altern Med 2006;6:35.

3. Velmurugan P, Kamaraj M, Prema D. Phytochemical constituents of Cadaba trifoliata Roxb. root extract. Int J Phytomed 2010;2:379-84

4. Rao CV, Sairam K, Goel RK. Experimental evaluation of Bocopa monniera on rat gastric ulceration and secretion. Indian J Physiol Pharmacol 2000;44:435-41.

5. Hemamalini G, Jithesh P, Nirmala P. Phytochemical analysis of leaf extract of plant Acacia nilotica by GC-MS method. Adv Biol Res 2013;7:141-4.

6. Karimi E, Jaafar HZ. HPLC and GC-MS determination of bioactive compounds in microwave obtained extracts of three varieties of Labisia pumila Benth. Molecules 2011;16:6791-805.

7. Robertson DG. Metabonomics in toxicology: A review. Toxicol Sci 2005;85:809-22.

8. Kell DB, Brown M, Davey HM, Dunn WB, Spasic I, Oliver SG, et al. Metabolic foot printing and systems biology: The medium is the message. Nat Rev Microbiol 2005;3:557-65.

9. Gamble JS, Fischer CE. Flora of the Presidency of Madras. Calcutta: Botanical Survey of India; 1957. p. 1-3.

10. Fyson PF. The Flora of the Nilgiri and Pulney Hill Tops. Madras: Superintendent, Government Press; 1915-20. p. 3

11. Matthew KM. The Flora of the Tamil Nadu Carnatic. Vol. 3. Tiruchirapalli: The Rapinet Herbarium, St. Joseph's College; 1983. p. 278-9.

12. Massada Y. Analysis of Essential oil by Gas Chromatography and 
Spectrometry. New York, London: Wiley Publication; 1976. p. 69-71.

13. Duke JA. Phytochemical and Ethnobotanical Databases. Available from: http://www.search.conduit.com/2012.

14. Dogruer SD, Onkol T, Ozkan S, Ozgen S, Fethi M. Synthesis and antimicrobial activity of some $3(2 \mathrm{H})$-pyridazinone and $1(2 \mathrm{H})$ phthalazinone derivatives. Turk J Chem 2008;3:469-79.

15. Praveenkumar P, Kumaravel S, Lalitha C. Screening of antioxidant activity, total phenolics and GC-MS study of Vitex negundo. Afr J Biochem Res 2010;4:191-5.

16. Sharmila S, Kalaichelvi K, Dhivya SM. Pharmacognostical and phytochemical analysis of Cayratia pedata var. Glabra-a vitaceae member. Int J Pharm Sci Res 2018;9:218-26.
17. Sharmila S, Kalaichelvi K, Dhivya SM. Pharmacognostic standardisation of Cayratia pedata (Lam.) Gagnep. var. glabra gamblean endemic and endangered medicinal climber in Thiashola, Nilgiris. Int J Pharm Pharm Sci 2017;9:57-63.

18. Samaha HS, Kelloff GJ, Steele V, Rao CV, Reddy BS. Modulation of apoptosis by sulindac, curcumin, phenylethyl-3-methylcaffeate, and 6-phenylhexyl isothiocyanate: Apoptotic index as a biomarker in colon cancer chemoprevention and promotion. Cancer Res 1997;57:1301-5.

19. Al-Keilani MS, Alsmadi DH. The HDAC inhibitor sodium phenylbutyrate enhances the cytotoxicity induced by 5 -fluorouracil, oxalip latin, and irinotecan in colorectal cancer. Int J Pharm Pharm Sci 2018;10:155-9. 